\title{
Challenging choice of safety factor for design of strip footings on gypsum-rich soils
}

\author{
Sabah Said Razouki ${ }^{1}$ Dina Kamal Kuttah ${ }^{2}$ (i)
}

Received: 5 February 2020 / Accepted: 6 May 2020 / Published online: 19 May 2020

(c) The Author(s) 2020

\begin{abstract}
A fine-grained gypsum-rich clayey soil having a gypsum content of $33 \%$ is subjected, in CBR moulds, to modified American association of state highway and transportation officials compaction at optimum moisture content. Two sets of samples were prepared. The first set remained unsoaked, while the second was soaked in fresh water for 120 days. From each CBR sample, three specimens were extracted for unconsolidated undrained triaxial test and the Mohr-Coloumb failure envelopes were obtained for soaked and unsoaked conditions. Soaked samples suffered a significant drop in both cohesion and angle of internal friction. The ultimate bearing capacity of a strip footing was calculated for each of soaked and unsoaked conditions revealing the critical region. For important structures on gypsum-rich soil, the paper shows that the allowable bearing capacity should be based on soaked condition. Based on unsoaked conditions, a safety factor of 8 is required to assure a safety factor of 3 based on soaked condition. For less important structures in regions of hot dry climate with low probability of soaking, safety factors of 4 and 3, based on unsoaked conditions, are required to give safety factors of 1.5 and 1.1 based on soaked conditions, respectively.
\end{abstract}

Keywords Challenging and problematic soils · Design methods and aids · Groundwater · Strength and testing of materials . Unsaturated soils

\section{List of symbols}

B Width of strip footing

c Soil cohesion

CBR California bearing ratio

$N_{c}, N_{q}, N_{\searrow}$ Terzaghi bearing capacity factors

OMC Optimum moisture content

$p_{0} \quad$ Overburden pressure

$q_{a} \quad$ Allowable bearing capacity

$q_{u} \quad$ Terzaghi's ultimate bearing capacity

$q_{u s} \quad$ Ultimate bearing capacity for soaked conditions

$q_{u и} \quad$ Ultimate bearing capacity for unsoaked conditions

Dina Kamal Kuttah

dina.kuttah@vti.se

Sabah Said Razouki

nspsf2004@yahoo.com

1 Civil Engineering, Al-Nahrain University, Baghdad, Iraq

2 Swedish National Road and Transport Research Institute (VTI), Linköping, Sweden

$\begin{array}{ll}\text { SF } & \begin{array}{l}\text { Safety factor (overall or global factor of } \\ \text { safety) }\end{array} \\ \phi & \text { Angle of internal friction } \\ \chi & \text { Unit weight of soil }\end{array}$

\section{Introduction}

Gypsum-rich soils in the form of gypsum sand and finegrained gypsiferous soils as well as gypsum rocks are of wide occurrence in the Middle East, especially in areas peripheral to the Red Sea and Arabian Gulf [1-4]. James and Lupton [5] studied the problems of gypsum rock in foundations of hydraulic structures, while Salih [6] studied thoroughly the stability of Mosul earth dam constructed on gypsum rocks in northern Iraq.

In the United Kingdom, Cooper and Saunders [7] pointed out that gypsum problems caused difficult conditions for bridge and road construction. Harris et al. [8] recommended stabilization of high-sulphate soils in Texas and Hunter [9] measured pavement heaves in Las Vegas, USA as high as $300 \mathrm{~mm}$ and wide cracks on pavement surface up to $150 \mathrm{~mm}$ width. 
Thus, gypsiferous soils are problematic soils requiring thorough study to enable the geotechnical engineer/pavement designer to arrive at a safe and economic solution taking into account that both soil strength and stiffness are affected by environmental conditions [10, 11].

\section{Background}

For geotechnical engineers, the soil strength is usually expressed in terms of the two soil strength parameters, namely the cohesion $\mathrm{c}$ and angle of internal friction $\phi$. In pavement engineering, the soil strength is usually expressed in terms of the California bearing ratio (CBR). The decrease in CBR of gypsum-rich soils due to dissolution of gypsum during longterm soaking in fresh water has received attention by various authors [12-14]. Razouki and El-Janabi [12] pointed out that for a silty sand, containing $64 \%$ of gypsum and compacted at the optimum moisture content and $95 \%$ of the modified AASHTO dry density, the unsoaked CBR of $34 \%$ decreased to $6 \%$ at the end of 180 days' soaking. This indicates the significant weakening of gypsum sand due to long-term soaking.

The improvement of gypsum-rich soil strength by increased compaction has been investigated by Razouki and Ibrahim [15] and Razouki et al. [16]. For gypsum sand having a gypsum content of $28 \%$, Razouki and Ibrahim [15] reported a significant increase in CBR value for both soaked and unsoaked conditions due to increase in compaction effort (10-70 blows/ layer) for soil samples compacted at the optimum moisture content of the modified AASHTO compaction. For finegrained gypsiferous soil having a gypsum content of $33 \%$ and compacted at optimum moisture content of the modified AASHTO compaction, Razouki et al. [16] used four different compaction efforts of 12, 25, 56 and 70 blows/layer. The CBR tests indicated a nonlinear increase in CBR with increasing compaction effort showing improvement in soil strength with increased compaction. However, Razouki et al. [16] focused attention on the fact of a significant drop in the CBR due to long-term soaking for all compaction efforts.

The soil strength parameters $\mathrm{c}$ and $\phi$ have received attention by Razouki et al. [17] and Razouki and Kuttah [18], who reported a significant decrease in both cohesion and angle of internal friction with increasing soakings' period in fresh water. In addition, Razouki et al. [17] pointed out that for gypsum-rich soils, use of four days soaking can lead to significant overestimation of soil strength.

\section{Aim of the study}

To achieve a safe and economic design of foundations on gypsum-rich soils, the geotechnical engineer aims at obtaining realistic values for the strength parameters that are affected significantly by the soaking conditions of the soil.
In practice, rise in groundwater table, long-term flooding, etc., are possible. This leads to weakening of the soil and can be very harmful for foundations on gypsum-rich soils. Thus, to avoid any possible bearing capacity failure, the aim of this paper is to study the decrease in both soil strength parameters and hence in ultimate bearing capacity of strip footings on gypsum-rich soil subjected to long-term soaking in fresh water. The comparison of the ultimate bearing capacity for soaked conditions with that for unsoaked conditions will allow the determination of the region of risk of a bearing capacity failure if any soaking takes place and the design was based on unsoaked conditions. This will allow a logical estimate of the factor of safety if the foundation design is based on unsoaked soil conditions.

\section{Bearing capacity}

According to Terzaghi et al. [19], the Terzaghi bearing capacity equation for strip footings under centric loading is:

$\mathrm{q}_{\mathrm{u}}=\mathrm{c} \mathrm{N} \mathrm{N}_{\mathrm{c}}+\mathrm{p}_{0} \mathrm{~N}_{\mathrm{q}}+0.5 \times B \mathrm{~N}_{x}$

where $q_{u}=$ Terzaghi's ultimate bearing capacity, $c=$ soil cohesion, $X=$ unit weight of soil, $p_{0}=$ overburden pressure, $B=$ width of strip footing, $N_{c}, N_{q}, N_{\Upsilon}=$ Terzaghi bearing capacity factors.

To avoid a bearing capacity failure, the allowable bearing capacity $\mathrm{q}_{\mathrm{a}}$ is obtained as follows:

$q_{a}=q_{u} / \mathrm{SF}$

where $\mathrm{SF}=$ safety factor (overall or global factor of safety).

The safety factor is based on the type of soil, reliability of the soil parameters, importance of the structure, and consultant caution especially when dealing with problematic soils [20].

Note that, the bearing capacity of shallow foundations under combined loading has been discussed thoroughly by Suryasentana et al. [21].

\section{Soil properties}

To show the serious effect of soaking on the bearing capacity of foundations on gypsum-rich soils, a fine-grained gypsumrich soil from the vicinity of Baghdad, Iraq, was chosen for this study.

According to ASTM D 4318-17 [22], the liquid limit was $29 \%$ and the plastic limit was $17 \%$ yielding a plasticity index of $12 \%$. The modified AASHTO compaction test [23] (method D) yielded a maximum dry density of $18.18 \mathrm{kN} / \mathrm{m}^{3}$ at an optimum moisture content of $11.5 \%$.

According to the BS 5930 [24], the soil belongs to CLG group and to CL group according to the unified soil 
classification system with a silt and clay fraction of about $68 \%$ [25]. Using the water-soluble sulphate method of BS 1377 [26], the sulphate as $\mathrm{SO}_{3}$ was found to be $15.2 \%$ and the corresponding gypsum content was $33 \%$ as calculated from sulphate content.

\section{Unconsolidated undrained triaxial tests}

For the purpose of studying the shear strength of the soil under study, it was decided to make use of the unconsolidated undrained triaxial test (UU test or quick test at a strain rate of $1.5 \mathrm{~mm} / \mathrm{min}$ ) on triaxial soil specimens.

To arrive at soil specimens for triaxial testing, two pairs of CBR soil samples were compacted at optimum moisture content and maximum dry density of the modified AASHTO compaction test. The first pair was left unsoaked, while the second pair was soaked in fresh water for 120 days to give enough time for gypsum to dissolve. For triaxial testing, three soil specimens were extracted from each CBR soil sample.

For each of soaked and unsoaked conditions, the three corresponding soil specimens were subjected to three different confining pressures namely 200,300 and $400 \mathrm{kPa}$ for the first, second and third specimen, respectively.

Figure 1 shows the Mohr-Coloumb failure envelope for each of soaked and unsoaked conditions. The effect of 120 days soaking on the cohesion and angle of internal friction of the tested soil is quite obvious. It can be seen from Fig. 1 that both soil strength parameters are affected by soaking. The cohesion decreased from $150 \mathrm{kPa}$ for unsoaked conditions to $100 \mathrm{kPa}$ for 120 days-soaked samples. Similarly, the angle of internal friction decreased from $27^{\circ}$ to $20^{\circ}$ upon soaking of the gypsiferous soil specimens for 120 days. The significant drop in soil strength in terms of cohesion and angle of internal friction due to long-term soaking can be attributed to the dissolution of cementing agent, gypsum, upon wetting that reduces the gypsum bonds between the soil particles. This fact of weakening of the soil due to soaking should not be overlooked when designing foundations on gypsum-rich soils.

Figure 2 shows the effect of soaking and confining pressure on the failure mode of tested triaxial soil specimens. It is obvious from this figure that at 120 days soaking, the soil specimens exhibit some ductility as compared to the unsoaked specimens. Thus, bulging occurs for specimens tested under $200 \mathrm{kPa}$ confining pressure and the number of observed slip surfaces reduces for soil specimens tested under 300 and $400 \mathrm{kPa}$ confining pressure indicating the transitional response from brittle to ductile failure mode.

\section{Factor of safety against bearing capacity failure of strip footings}

To show the significant decrease in factor of safety of strip footings on gypsum-rich soil due to soaking in fresh water, the bearing capacity will be studied for both unsoaked and soaked conditions of the soil under study.

Noting that the angle of internal friction $\phi=27^{\circ}-20^{\circ}$ for unsoaked and soaked conditions, respectively, Table 1 shows Terzaghi bearing capacity factors $[19,20]$ for both conditions. For a foundation depth of $1 \mathrm{~m}$ and a width of
Fig. 1 Mohr-Coulomb failure envelopes for soaked and unsoaked conditions of tested gypsum-rich soil subjected to modified AASHTO compaction at $\mathrm{OMC}$

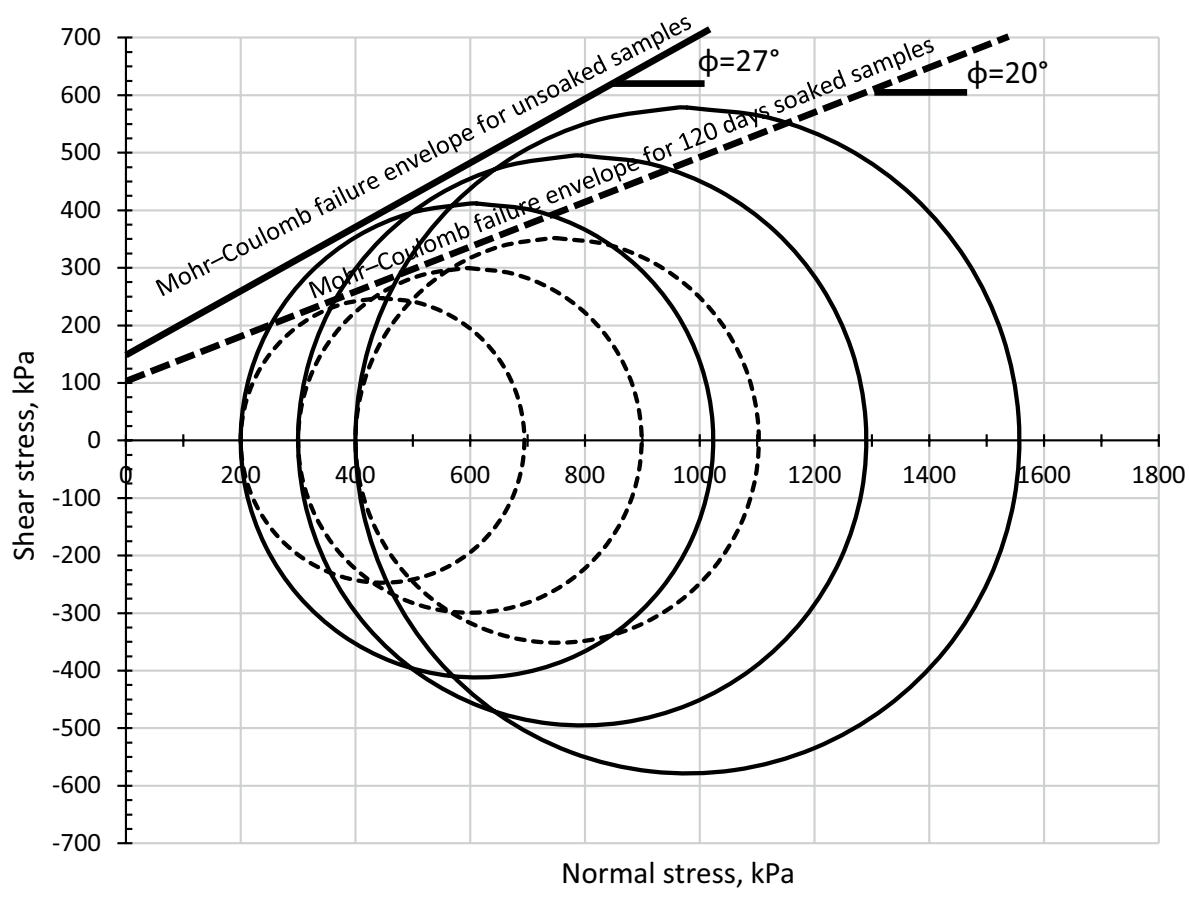


Fig. 2 Effect of soaking on the failure mode of triaxial soil samples compacted at modified AASHTO compaction at OMC
Samples soaked for 120 days
Unsoaked Samples

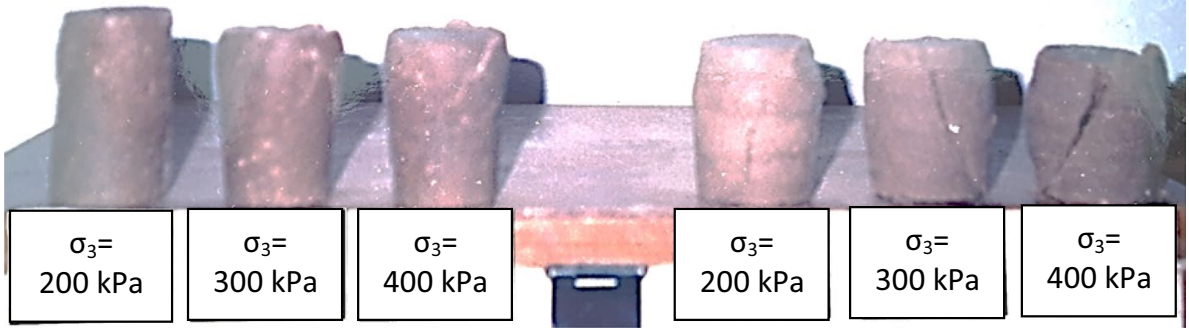

Table 1 Bearing capacity for strip footing under different conditions

\begin{tabular}{llllll}
\hline $\begin{array}{l}\text { Width of Strip } \\
\text { footing (m) }\end{array}$ & Condition & \multicolumn{2}{l}{ Bearing capacity factors } & \multicolumn{2}{c}{$\begin{array}{l}\text { Ultimate bearing } \\
\text { capacity (kPa) }\end{array}$} \\
\cline { 2 - 5 } & & $N_{c}$ & $N_{q}$ & $N_{\Upsilon}$ & \\
\hline 1 & Unsoaked & 29.94 & 16.62 & 13.7 & 4966.74 \\
& Soaked & 17.7 & 7.4 & 5.0 & 1871.68 \\
4 & Unsoaked & As for 1 m width above & & & 5383.29 \\
& Soaked & As for 1 m width above & & & 2632.7
\end{tabular}

strip footing of $1 \mathrm{~m}$ as well as $4 \mathrm{~m}$, the use of Eq. 1 with a bulk unit weight of the tested soil of $20.27 \mathrm{kN} / \mathrm{m}^{3}$ and a submerged unit weight of $10.27 \mathrm{kN} / \mathrm{m}^{3}$ yields the bearing capacities shown in Table 1. Thus, the ratio of ultimate bearing capacity $q_{u s}$ for soaked conditions to that $q_{u u}$ for unsoaked conditions becomes $1871.68 / 4966.74=0.377$ for the case of $1 \mathrm{~m}$ width and $2632.7 / 5383.29=0.489$ for $4 \mathrm{~m}$ width. This indicates the significant effect of long-term soaking on the reduction of bearing capacity and that an increase in footing width has a little effect on increasing the bearing capacity. Thus, for important structures, the safest design should be based on fully soaked conditions.

For a factor of safety of three, the allowable bearing capacity for soaked conditions and $1 \mathrm{~m}$ footing width becomes $1871.68 / 3=623.89 \mathrm{kPa}$. However, if the design is based on unsoaked conditions data, then a factor of safety of 8 is needed to yield an allowable bearing capacity of $4966.74 / 8=620.84 \mathrm{kPa}$ close to that corresponding to soaked conditions.

Table 2 shows that similar conclusions apply for the case of $4 \mathrm{~m}$ strip footing width.

Figure 3 shows the variation of the bearing capacity with width of strip foundation for both soaked and unsoaked conditions indicating the critical region where the factor of safety is less than one with respect to soaked conditions.

Thus, the choice of factor of safety is a challenging problem for foundations on gypsum-rich soils. For safe design of foundations on such soils, a logical selection of factor of safety against bearing capacity failure is required. As gypsum-rich soils are usually found in areas of hot dry climate, the designer may accept the unsoaked conditions for
Table 2 Allowable bearing capacity for strip footing for soaked and unsoaked conditions

\begin{tabular}{|c|c|c|c|}
\hline \multicolumn{2}{|c|}{ Factor of safety } & \multicolumn{2}{|c|}{ Allowable bearing capacity $(\mathrm{kPa})$} \\
\hline $\begin{array}{l}\text { Soaked } \\
\text { conditions }\end{array}$ & $\begin{array}{l}\text { Unsoaked } \\
\text { conditions }\end{array}$ & Soaked conditions & Unsoaked conditions \\
\hline \multirow[t]{2}{*}{3} & 8 & $623.89^{\mathrm{a}}$ & $620.84^{\mathrm{a}}$ \\
\hline & & $877.57^{\mathrm{b}}$ & $672.9^{\mathrm{b}}$ \\
\hline \multirow[t]{2}{*}{1.5} & 4 & $1247.79^{\mathrm{a}}$ & $1241.69^{\mathrm{a}}$ \\
\hline & & $1755.13^{\mathrm{b}}$ & $1345.82^{\mathrm{b}}$ \\
\hline \multirow[t]{2}{*}{1.1} & 3 & $1701.53^{\mathrm{a}}$ & $1655.38^{\mathrm{a}}$ \\
\hline & & $2393.36^{\mathrm{b}}$ & $1794.43^{\mathrm{b}}$ \\
\hline
\end{tabular}

${ }^{\mathrm{a}}$ For $1 \mathrm{~m}$ strip footing width

${ }^{\mathrm{b}}$ For $4 \mathrm{~m}$ strip footing width

determining the allowable bearing capacity. If the foundation soil becomes soaked, then there is a great probability of bearing capacity failure for the common factor of safety of three.

However, if the probability of long-term soaking is low and the design is to be based on unsoaked condition data, then it is logical to adopt, for important structures, a factor of safety of 1.5 for soaked conditions. Table 2 and Fig. 4 show that a factor of safety of about 4 is required if the design is to be based on unsoaked condition data.

For less important structures and low probability of longterm soaking, a factor of safety of 1.1 for soaked conditions may be adopted. Table 2 and Fig. 4 show that a factor of safety of 3 is required if the allowable bearing capacity is to be based on unsoaked conditions. 
Fig. 3 Variation of ultimate bearing capacity with width of strip footing for soaked and unsoaked conditions defining the critical region

Fig. 4 Variation of allowable bearing capacity with width of strip footing indicating corresponding factors of safety for soaked and unsoaked conditions
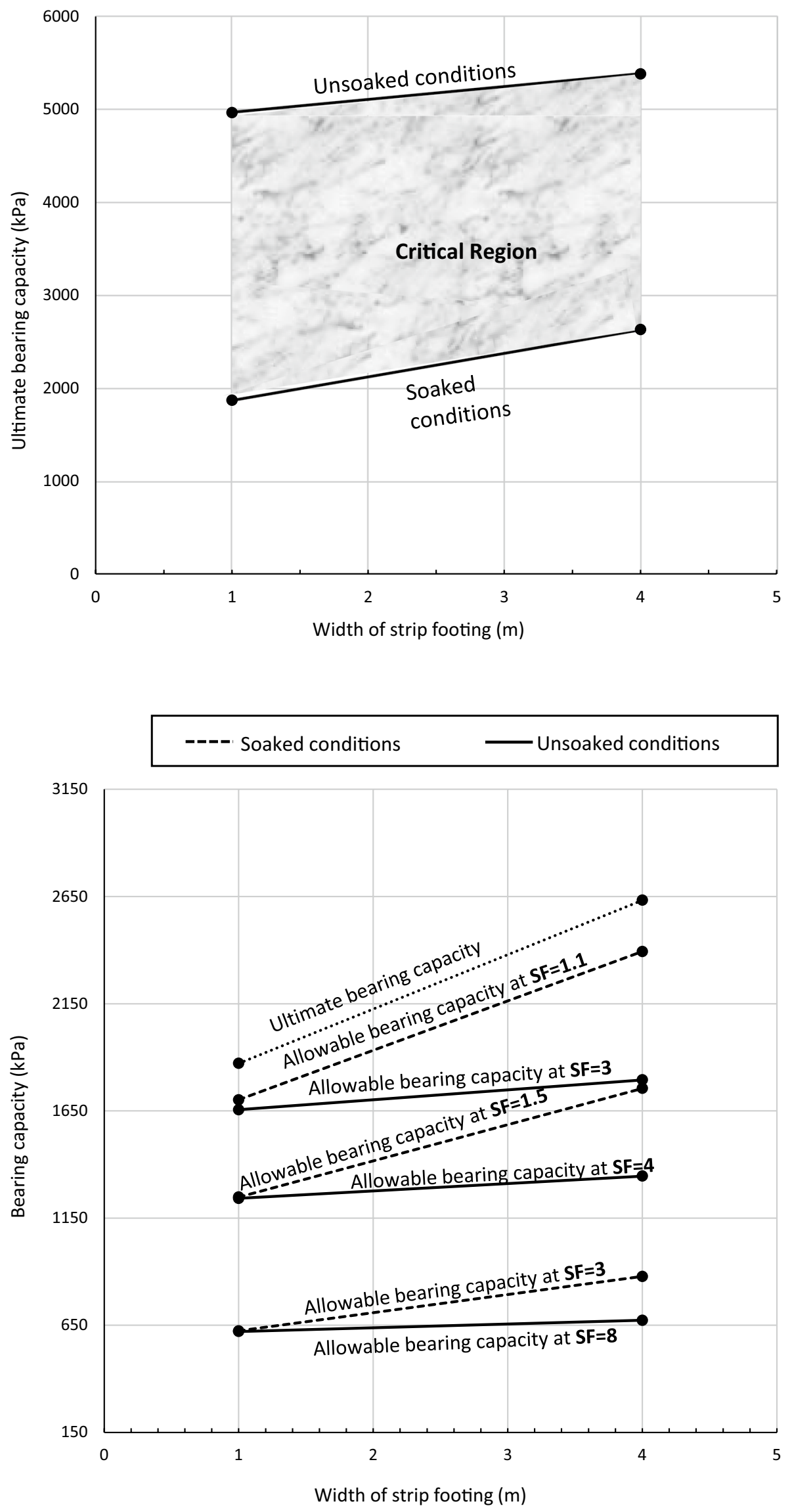


\section{Conclusions}

The main conclusions of this work can be summarized as follows:

- The decrease in cohesion of the tested gypsum-rich soil from $150 \mathrm{kPa}$ to $100 \mathrm{kPa}$ and the angle of internal friction from $27^{\circ}$ to $20^{\circ}$ due to long-term soaking is highly significant and must be taken into account in foundation design.

- The ultimate bearing capacity for a strip footing of $1 \mathrm{~m}$ width for soaked conditions of the tested soil is $37.68 \%$ of that for unsoaked conditions. This indicates the necessity of considering long-term soaking for design of foundations on gypsum-rich soils to avoid any bearing capacity failure.

- If for any reason, the design of foundations on gypsumrich soils for important structures has to be based on unsoaked conditions, then a safety factor of 8 for the tested soil should preferably be chosen to assure a factor of safety of 3 for expected soaked conditions.

- For the case of low probability of long-term soaking, a factor of safety of 4 for soils similar to the tested soil may be adopted if the design to be based on unsoaked condition data to provide a safety factor of 1.5 for soaked conditions.

- For less important structures and seldom occurrence of long-term soaking, a factor of safety of 3 can be adopted for design based on unsoaked condition to provide a safety factor of 1.1 for soaked conditions.

Acknowledgements Open access funding provided by Swedish National Road and Transport Research Institute (VTI).

Open Access This article is licensed under a Creative Commons Attribution 4.0 International License, which permits use, sharing, adaptation, distribution and reproduction in any medium or format, as long as you give appropriate credit to the original author(s) and the source, provide a link to the Creative Commons licence, and indicate if changes were made. The images or other third party material in this article are included in the article's Creative Commons licence, unless indicated otherwise in a credit line to the material. If material is not included in the article's Creative Commons licence and your intended use is not permitted by statutory regulation or exceeds the permitted use, you will need to obtain permission directly from the copyright holder. To view a copy of this licence, visit http://creativecommons.org/licenses/by/4.0/.

\section{References}

1. James AN, Kirkpatrick IM (1980) Design of foundations of dams containing soluble rocks and soils. Q J Eng Geol 13:189-198

2. Fookes PC, French WJ, Rice SMM (1985) The influence of ground and groundwater geochemistry on construction in the Middle East. Q J Eng Geol 18(2):101-128

3. Horta JC (1985) Salt heaving in the Sahara. Geotechnique 35(3):329-337
4. Tomlinson MJ, Boorman R (2001) Foundation design and construction, 7th edn. Longman Group, London

5. James AN, Lupton RR (1978) Gypsum and anhydrite in foundations of hydraulic structures. Geotechnique 28(3):249-272

6. Salih NB (2013) Stability of dams constructed on problematic substrates. Ph.D. thesis, School of Engineering and Design. Brunel University, London, UK

7. Cooper AH, Saunders JM (2002) Road and bridge construction across gypsum karst in England. Eng Geol 65(2-3):217-223

8. Harris P, Von Holdt J, Sebasta S, Scullion T (2005) Recommendations for stabilization of high sulfate soils in Texas. Report 0-4240-3. Texas Transportation Institute, USA

9. Hunter D (1988) Lime-induced heave in sulfate-bearing clay soils. Proc ASCE J Geotech Eng 114(2):150-167

10. Razouki SS, Salem BM (2016) Frequency effect of cyclic soaking and drying on the resilient modulus of gypsum-rich roadbed sand. Transp Geotech 7:13-20

11. Razouki SS, Salem BM (2017) Gypsum sand resilient modulus during cyclic soaking and drying. Int J Pavement Eng 18(2):110-120

12. Razouki SS, El-Janabi O (1999) Decrease in the CBR of a gypsiferous soil due to long-term soaking. Q J Eng Geol 32(1):87-89

13. Razouki SS, Kuttah DK (2004) Effect of soaking period and surcharge load on resilient modulus and California bearing ratio of gypsiferous soils. Q J Eng Geol Hydrol 37:155-164

14. Razouki SS, Kuttah DK (2006) Predicting long-term soaked CBR of gypsiferous subgrade soils. Proc Inst Civ Eng Transp 159(3):135-140

15. Razouki SS, Ibrahim AN (2007) Improving a gypsum roadbed soil by increased compaction. Proc Inst Civ Eng Transp J 160(1):27-3

16. Razouki SS, Kuttah DK, Al-Damluji O, Nashat I (2012) Improving fine-grained gypsiferous soil by increased compaction. Int $\mathrm{J}$ Pavement Eng 13(1):32-38

17. Razouki SS, Kuttah DK, Al-Damluji OA, Nashat IH (2006) Strength erosion of a fine-grained gypsiferous soil during soaking. Arab J Sci Eng 32(1B):147-152

18. Razouki SS, Kuttah DK (2019) Behaviour of fine- grained gypsum-rich soil under triaxial tests. Proc Inst Civ Eng Constr Mater. https://doi.org/10.1680/jcoma.1800041

19. Terzaghi K, Peck RB, Mesri G (1996) Soil mechanics in engineering practice, 3rd edn. Wiley, Hoboken

20. Bowles JE (2001) Foundation analysis and design, 5th edn. McGraw-Hill International Editions, New York

21. Suryasent SK, Dunne HP, Martin CM, Burd HJ, Byrne BW, Shonberg A (2020) Assessment of numerical procedures for determining shallow foundation failure envelopes. Geotechnique 70(1):60-70

22. ASTM D4318-17 (2017) Standard Test Methods for Liquid Limit, Plastic Limit, and Plasticity Index of Soils, ASTM International, West Conshohocken, PA, www.astm.org

23. AASHTO T 180(2018) Standard Method of Test for MoistureDensity Relations of Soils Using A $4.54 \mathrm{Kg}(10-\mathrm{Lb})$ Rammer and A 457-mm (18-In.) Drop. American Association of State and HighwayTransportation Officials, Washington, DC, USA

24. BS 5930 (2015) Code of Practice for Ground Investigations. The British Standards Institution. BSI standardsPublication, London

25. ASTM D2487-11 (2011) Standard Practice for Classification of Soils for Engineering Purposes (Unified Soil Classification System), ASTM International, West Conshohocken, PA, www.astm. org

26. BS 1377-3 (2018) Methods of Test for Soils for Civil Engineering Purposes. Chemical and Electro-Chemical Testing. The British Standards Institution. BSI standards Publication, London 